\title{
The New Method to Determine Ownership Stake to Exercise Control: An Empirical Analysis on Italian Companies
}

\author{
Carmelo Intrisano, Anna Paola Micheli \\ University of Cassino and Southern Lazio, Cassino, Italy
}

\begin{abstract}
The idea of this work arises from the analysis of the researches developed in the literature on topic of ownership and control that are mostly based on threshold of ownership stake to determine control equal for all companies and, in most cases, not supported by theoretical arguments and empirical evidences. In fact, the aim of this paper is to build a new method of determining the threshold of ownership stake that allows the shareholder to exercise control. In particular, this survey uses all Italian listed companies as reference, and the minutes of the Ordinary and Extraordinary General Meetings of shareholders, in 2009-2012, as database. The topic can be enriched with further and future researches aiming to adapt this new method in a cross-country investigation and so to identify the different threshold for the countries, on the basis of the different national laws regarding the ownership stakes that affect the control.
\end{abstract}

Keywords: ordinary and extraordinary general meetings of shareholders, control threshold, quorum, control, annual financial statement approval, renewal of boards

\section{Introduction}

The topic about the relationship between ownership structure and control has undergone relevant theoretical developments over time, starting from the assumption of a diffuse ownership structure (Berle \& Means, 1932; Baumol, 1959; Jensen \& Meckling, 1976; Grossman \& Hart, 1980) and coming to the recognition of a relevant presence of more or less concentrated ownership structures in different countries (Demsetz, 1983; Shleifer \& Vishny, 1986; Morck, Shleifer, \& Vishny, 1988).

In most investigations and, more generally, in the literature of reference, the controlling shareholder is identified by setting a threshold of ownership that distinguishes the condition of controlling shareholder from the condition of non-controlling shareholder. The measure of such ownership has been hypothesized by researchers that, in most cases, come to this determination without testing and demonstrating the hypothesis.

Thus, for example, La Porta, Lopez-de-Silanes, and Shleifer (1999), in their cross-country work on ownership structure, use two alternative measures of threshold, $10 \%$ and $20 \%$, simply on the basis of the following assumptions, to identify the last shareholder of the sampled companies. The $10 \%$ would represent a relevant threshold of votes, given that many countries link the mandatory disclosure to the ownership stake,

Carmelo Intrisano, Professor of Corporate Finance, Department of Economy and Law, University of Cassino and Southern Lazio.

Anna Paola Micheli, Ph.D., Research Fellow in Corporate Finance, Department of Economy and Law, University of Cassino and Southern Lazio.

Correspondence concerning this article should be addressed to Carmelo Intrisano, Sant' Angelo Road, Cassino, Italy. E-mail: c.intrisano@eco.unicas.it. 
which normally does not exceed $10 \%$. This is, as you note, a justification characterized by evident signs of weakness. In fact, it does not illustrate the relationship between mandatory disclosure and threshold: it does not explain the reasons why the threshold of ownership that involves the mandatory disclosure is sufficient to exercise control. Even less, this report, although inconsistent in terms of the theoretical arguments, should be supported by specific tests. Similarly, the idea of the $20 \%$ as the ownership threshold that, according to the researchers, is sufficient for the effective control of a company, appears unfounded on theoretical basis regarding the ownership structure.

Even Faccio and Lang (2002) in their research on the ownership structure of Western Europe, assume that $20 \%$ of the shares with voting rights are sufficient to ensure control, justifying this decision on the basis that the assumption is in line with previous studies.

The $20 \%$ shares, as the control threshold, is also assumed by Villalonga and Amit (2006) among the different conditions taken to ascertain whether family firms create more value of other ownership structures.

The same measure is used by Dick and Zingales (2004) in their cross-country investigation on private benefits, individuating the potential candidates to exercise control amongst the buyers of shareblocks, which cross from a position where they hold less than $20 \%$ of the shares to a position in which they hold more than $20 \%$.

Instead, Barontini and Caprio (2006), in their empirical work on the effects of family control on firm value, set a threshold of $10 \%$ to select widely-held companies and assuming that a company is to be considered as a widespread ownership where no shareholder owns more than $10 \%$ of the voting rights.

Table 1

Ownership Threshold in Literature

\begin{tabular}{|l|l|l|l|}
\hline Author & Size & Reason & Paper \\
\hline \multirow{2}{*}{ La Porta et al. (1999) } & $10 \%$ & $\begin{array}{l}\text { Many countries link the mandatory } \\
\text { disclosure to the ownership stake, } \\
\text { which normally does not exceed 10\% }\end{array}$ & Corporate ownership around the world \\
\cline { 2 - 4 } & $20 \%$ & $\begin{array}{l}\text { Sufficient measure to exercise the } \\
\text { effective control }\end{array}$ & The ultimate ownership of Western European corporations \\
\hline Faccio and Lang (2000) & $20 \%$ & In line with other studies & $\begin{array}{l}\text { How do family ownership, management and control affect } \\
\text { firm value? }\end{array}$ \\
\hline $\begin{array}{l}\text { Villalonga and Amit } \\
\text { (2006) }\end{array}$ & $20 \%$ & In line with other studies & Private benefits of control: An international comparison \\
\hline $\begin{array}{l}\text { Dyck and Zingales (2004) } \\
\text { Barontini and Caprio } \\
\text { (2006) }\end{array}$ & $10 \%$ & In line with other studies & $\begin{array}{l}\text { The effect of family control on firm value and } \\
\text { performance: Evidence from Continental Europe }\end{array}$ \\
\hline
\end{tabular}

Therefore, this work provides a theoretical contribution to the reference literature suggesting a new method of determining the threshold of ownership, specially tested for the purpose.

Starting from these theoretical references, the paper is organized as follows. Section one describes the methodological aspects of the empirical analysis and, in particular, observations, comments, variables, and the descriptive statistics. Section two outlines the survey results. Section three shows the characteristic features of the new method, specifically constructed to determine the control threshold. Section four, finally, is devoted to conclusions.

\section{Methodology}

The empirical evidence distinguishes relevant shareholders by non-relevant shareholders depending on the relative ownership greater or less than $2 \%$ of the share capital represented by shares with voting rights, in line with the Italian Regulation implementing Legislative Decree 24 February 1998, No. 58, regarding the 
regulation of issuers adopted by the Commissione Nazionale per le Società e la Borsa (CONSOB) with resolution No. 11971 of 14 May 1999.

Assuming that the interest of the owners to the general shareholders' meeting is different depending on the object and considering that the main manifestations and demonstrations of control during the meeting are the resolutions adopted in the approval of the annual financial statement and in the board renewal, this research has been focused on the analysis of the general shareholders' meetings that have the above agendas.

This empirical evidence considers all listed companies in the Italian market, excluding the banking and insurance sectors, since the specific regulations can affect the dynamic of control. It also excludes the companies for which it was not possible to acquire the corporate documents or otherwise those for which the available information is insufficient for the analysis.

Consequently all the minutes of the ordinary shareholders' meeting of the 2009-2012 period are analyzed, distinguishing, as mentioned, those concerning the approval of the annual financial statement from those concerning the board renewal, since the intensity of the interest to participate at the meeting are different in the shareholders. In fact, the general meeting for the approval of annual financial statement should arouse a greater involvement on the part of non-controlling shareholders in view of their interest in the dividends that follow the same approval. On the contrary, the meeting for the board renewal should motivate especially the relevant shareholders who see this as a means to exercise control.

All this generates a database of 798 distinct observations per year, of which 590 and 208 respectively having as agenda regard the approval of annual financial statement and the renewal of boards, as reported in Table 2 .

Table 2

Observation for Years and Agendas

\begin{tabular}{lrrrrr}
\hline & 2009 & 2010 & 2011 & 2012 & Total \\
\hline Approval of annual financial statement & 153 & 153 & 152 & 132 & 590 \\
Renewal of boards & 54 & 49 & 50 & 55 & 208 \\
Total & 207 & 192 & 202 & 187 & 798 \\
\hline
\end{tabular}

To determine the degree of involvement by relevant shareholders and non-relevant shareholders, the present investigation considers the following variables:

- Relevant shareholders number in the share capital;

- Relevant ownership stake in the share capital;

- Shareholders number present at the meeting;

- Ownership stake present at the meeting;

- Relevant shareholders number present at the meeting;

- Relevant ownership stake present at the meeting;

- Non-relevant shareholders number present at the meeting;

- Non-relevant ownership stake present at the meeting.

\section{Empirical Evidence}

For both agendas, the descriptive statistics shows the statistical significance of the mean for the variables considered, with the exception of shareholders number present at the meeting and non-relevant shareholders 
number present at the meeting. These variables, in fact, show in the period 2009-2012 relevant differences between mean and median that explain the asymmetry of the relative distributions as evidenced in Tables 3 and 4 .

Table 3

Descriptive Statistics: General Shareholders' Meeting for the Approval of the Annual Financial Statement

\begin{tabular}{|c|c|c|c|c|c|}
\hline & & 2009 & 2010 & 2011 & 2012 \\
\hline \multirow[t]{3}{*}{ Relevant shareholders number in the share capital } & Mean & 4.27 & 4.07 & 4.00 & 4.07 \\
\hline & Median & 4.00 & 3.50 & 3.00 & 4.00 \\
\hline & Dev.std & 2.26 & 2.27 & 2.25 & 2.34 \\
\hline \multirow[t]{3}{*}{ Relevant ownership stake in the share capital } & Mean & 68.12 & 66.82 & 66.16 & 67.33 \\
\hline & Median & 69.27 & 67.52 & 67.56 & 68.62 \\
\hline & Dev.std & 12.62 & 12.58 & 14.80 & 13.39 \\
\hline \multirow[t]{3}{*}{ Shareholders number present at the meeting } & Mean & 27.44 & 38.19 & 85.01 & 78.79 \\
\hline & Median & 14.00 & 15.00 & 15.00 & 21.50 \\
\hline & Dev.std & 44.24 & 67.50 & 313.57 & 174.96 \\
\hline \multirow[t]{3}{*}{ Ownership stake present at the meeting } & Mean & 64.37 & 63.47 & 65.53 & 67.20 \\
\hline & Median & 64.27 & 64.60 & 68.02 & 69.70 \\
\hline & Dev.std & 12.27 & 12.80 & 15.45 & 12.67 \\
\hline \multirow[t]{3}{*}{ Relevant shareholders number present at the meeting } & Mean & 2.72 & 2.66 & 2.80 & 2.92 \\
\hline & Median & 2.00 & 2.00 & 2.00 & 2.00 \\
\hline & Dev.std & 1.89 & 2.13 & 2.15 & 2.12 \\
\hline \multirow[t]{3}{*}{ Relevant ownership stake present at the meeting } & Mean & 61.20 & 60.38 & 60.97 & 62.21 \\
\hline & Median & 61.59 & 62.88 & 63.16 & 62.87 \\
\hline & Dev.std & 13.25 & 13.66 & 15.68 & 13.98 \\
\hline \multirow[t]{3}{*}{ Non-relevant shareholders number present at the meeting } & Mean & 24.74 & 35.53 & 82.23 & 75.86 \\
\hline & Median & 11.00 & 11.00 & 12.50 & 18.50 \\
\hline & Dev.std & 44.34 & 67.59 & 313.80 & 175.16 \\
\hline \multirow[t]{3}{*}{ Non-relevant ownership stake present at the meeting } & Mean & 3.17 & 3.09 & 4.62 & 4.99 \\
\hline & Median & 1.92 & 1.85 & 2.45 & 2.36 \\
\hline & Dev.std & 3.75 & 3.50 & 5.43 & 5.75 \\
\hline
\end{tabular}

Note. Source: our elaboration on corporate documents.

Table 4

Descriptive Statistics: General Shareholders' Meeting for Board Renewal

\begin{tabular}{|c|c|c|c|c|c|}
\hline & & 2009 & 2010 & 2011 & 2012 \\
\hline \multirow[t]{3}{*}{ Relevant shareholders number in the share capital } & Mean & 4.67 & 3.98 & 4.02 & 4.18 \\
\hline & Median & 4.00 & 3.00 & 4.00 & 4.00 \\
\hline & Dev.std & 2.24 & 2.26 & 1.89 & 2.60 \\
\hline \multirow[t]{3}{*}{ Relevant ownership stake in the share capital } & Mean & 67.15 & 68.79 & 64.44 & 69.37 \\
\hline & Median & 67.52 & 69.54 & 67.72 & 70.63 \\
\hline & Dev.std & 10.60 & 14.03 & 16.57 & 10.82 \\
\hline \multirow[t]{3}{*}{ Shareholders number present at the meeting } & Mean & 23.28 & 29.96 & 64.48 & 60.95 \\
\hline & Median & 14.00 & 15.00 & 14.00 & 22.00 \\
\hline & Dev.std & 22.62 & 37.64 & 126.60 & 106.99 \\
\hline \multirow[t]{3}{*}{ Ownership stake present at the meeting } & Mean & 63.96 & 65.53 & 65.51 & 68.86 \\
\hline & Median & 61.92 & 65.25 & 69.12 & 70.20 \\
\hline & Dev.std & 10.06 & 14.45 & 16.46 & 10.53 \\
\hline \multirow[t]{3}{*}{ Relevant shareholders number present at the meeting } & Mean & 3.06 & 2.56 & 2.94 & 3.04 \\
\hline & Median & 2.50 & 2.00 & 3.00 & 2.00 \\
\hline & Dev.std & 2.06 & 1.89 & 1.82 & 2.54 \\
\hline
\end{tabular}


(Table 4 continued)

\begin{tabular}{|c|c|c|c|c|c|}
\hline & & 2009 & 2010 & 2011 & 2012 \\
\hline \multirow[t]{3}{*}{ Relevant ownership stake present at the meeting } & Mean & 60.24 & 62.46 & 59.70 & 64.37 \\
\hline & Median & 60.31 & 63.75 & 64.30 & 65.46 \\
\hline & Dev.std & 11.02 & 15.53 & 17.65 & 11.88 \\
\hline \multirow[t]{3}{*}{ Non-relevant shareholders number present at the meeting } & Mean & 20.22 & 27.45 & 61.54 & 57.91 \\
\hline & Median & 11.02 & 10.00 & 11.50 & 19.00 \\
\hline & Dev.std & 22.81 & 37.99 & 126.51 & 107.45 \\
\hline \multirow[t]{3}{*}{ Non-relevant ownership stake present at the meeting } & Mean & 3.71 & 3.06 & 5.81 & 4.49 \\
\hline & Median & 2.02 & 1.88 & 3.32 & 2.12 \\
\hline & Dev.std & 4.87 & 3.45 & 6.29 & 5.61 \\
\hline
\end{tabular}

Note. Source: our elaboration on corporate documents.

Consequently, the analysis of this empirical work is based on the other six variables that have a lower difference between mean and median, and it is so low that the distributions are symmetrical. For these items, the explanatory power of the mean is further confirmed by the low dispersion of the results.

The analysis on these variables leads to similar results regarding the two agendas of ordinary shareholders' meeting. In particular, the meeting for the approval of the annual financial statement shows a substantial stability in the four years examined, as shown in Table 5.

Table 5

Shareholders' Meeting for the Approval of the Annual Financial Statement (Mean)

\begin{tabular}{lrrrr}
\hline & 2009 & 2010 & 2011 & 2012 \\
\hline Relevant shareholders number in the share capital & 4.27 & 4.07 & 4.00 & 4.07 \\
Relevant ownership stake in the share capital & 68.12 & 66.82 & 66.16 & 67.33 \\
Ownership stake present at the meeting & 64.37 & 63.47 & 65.53 & 67.20 \\
Relevant shareholders number present at the meeting & 2.72 & 2.66 & 2.80 & 2.92 \\
Relevant ownership stake present at the meeting & 61.20 & 60.38 & 60.97 & 62.21 \\
Non-relevant ownership stake present at the meeting & 3.17 & 3.09 & 4.62 & 4.99 \\
\hline
\end{tabular}

Note. Source: our elaboration on corporate documents.

The mean of relevant shareholders number in the share capital does not undergo large changes during the four years, assuming values around 4, as well as the mean of relevant ownership stake in the share capital shows values between $66.16 \%$ and $68.12 \%$. Similarly, the mean of relevant shareholders number present at the meeting is constant over the four years and has values around 3 equal to the mean of relevant ownership stake present at the meeting which varies slightly in the range from 63.47 to 67.20.

From all this, it is possible to deduce the following conclusions.

At the general meeting for approval of the annual financial statement the overall ownership stake of non-relevant ownership stake present at the meeting is very low, oscillating between $3.09 \%$ and $4.99 \%$ of the total share capital, unlike the overall ownership stake of relevant ownership stake present at the meeting that is very high, since which has values between the minimum of $60.38 \%$ and the maximum of $62.21 \%$. In brief, the minority shareholders, in their totality, represent a mean so limited that does not affect the dynamics of the control. 
The meeting for renewal of board shows values for the means of the variables analyzed not particularly different from those of the previous variables. The mean of the overall ownership stake of Non-relevant ownership stake present at the meeting is very low, oscillating between $3.06 \%$ and $5.81 \%$ of the total share capital, unlike the overall ownership stake of relevant ownership stake present at the meeting that is very high, since it has values between the minimum of $59.70 \%$ and the maximum of $64.37 \%$, as shown in Table 6.

Table 6

Shareholders' Meeting for Board Renewal (Mean)

\begin{tabular}{lrrrr}
\hline & 2009 & 2010 & 2011 & 2012 \\
\hline Relevant shareholders number in the share capital & 4.67 & 3.98 & 4.02 & 4.18 \\
Relevant ownership stake in the share capital & 67.15 & 68.79 & 64.44 & 69.37 \\
Ownership stake present at the meeting & 63.96 & 65.53 & 65.51 & 68.86 \\
Relevant shareholders number present at the meeting & 3.06 & 2.56 & 2.94 & 3.04 \\
Relevant ownership stake present at the meeting & 60.24 & 62.46 & 59.70 & 64.37 \\
Non-relevant ownership stake present at the meeting & 3.71 & 3.06 & 5.81 & 4.49 \\
\hline
\end{tabular}

Note. Source: our elaboration on corporate documents.

Briefly, for both shareholders' meeting there is a substantial absence of non-relevant shareholders, as further confirmed from Tables 7 and 8.

In fact, at the shareholders' meeting for annual financial statement, opposite to a mean absence of relevant shareholders that never exceeds the $10 \%$ of the overall ownership stake of relevant shareholders in the share capital, the mean absence of non-relevant shareholders never drops below the value of $85 \%$ of the overall ownership stake of non-relevant shareholders in the share capital.

Table 7

Shareholders' Meeting for the Approval of Annual Financial Statement: Ownership not Present (Mean)

\begin{tabular}{lrrrr}
\hline & 2009 & 2010 & 2011 & 2012 \\
\hline Ownership stake not present at the shareholders' meeting & 35.63 & 36.53 & 34.47 & 32.80 \\
Relevant ownership stake not present at the shareholders' meeting & 6.91 & 6.45 & 5.19 & 5.12 \\
Non-relevant ownership stake not present at the shareholders' meeting & 28.72 & 30.08 & 29.28 & 27.68 \\
\hline
\end{tabular}

Note. Source: our elaboration on corporate documents.

Table 8

Shareholders' Meeting for the Approval of Annual Financial Statement: Ownership not Present (Ratio)

\begin{tabular}{llrrr}
\hline & 2009 & 2010 & 2011 & 2012 \\
\hline Relevant ownership stake not present at the shareholders' meeting (ratio) & $10 \%$ & $10 \%$ & $8 \%$ & $8 \%$ \\
Non-relevant ownership not present at the shareholders' meeting (ratio) & $90 \%$ & $91 \%$ & $86 \%$ & $85 \%$ \\
\hline
\end{tabular}

Note. Source: our elaboration on corporate documents.

Similarly, as shown in Tables 9 and 10, at the shareholders' meeting for board renewal, opposite to a mean absence of relevant shareholders that never exceeds the $10 \%$ of the overall ownership stake of relevant shareholders in the share capital, the mean absence of non-relevant shareholders never drops below the value of $84 \%$ of the overall ownership stake of non-relevant shareholders in the share capital. 
Table 9

Shareholders' Meeting for Board Renewal: Ownership not Present (Mean)

\begin{tabular}{lrrrr}
\hline & 2009 & 2010 & 2011 & 2012 \\
\hline Ownership stake not present at the shareholders' meeting & 36.04 & 34.47 & 34.49 & 31.14 \\
Relevant ownership stake not present at the shareholders' meeting & 6.91 & 6.33 & 4.74 & 5.00 \\
Non-relevant ownership stake not present at the shareholders' meeting & 29.13 & 28.14 & 29.75 & 26.14 \\
\hline
\end{tabular}

Note. Source: our elaboration on corporate documents.

Table 10

Shareholders' Meeting for Board Renewal: Ownership not Present (Ratio)

\begin{tabular}{lrrrr}
\hline & 2009 & 2010 & 2011 & 2012 \\
\hline Relevant ownership stake not present at the shareholders' meeting (ratio) & $10 \%$ & $9 \%$ & $7 \%$ & $7 \%$ \\
Non-relevant ownership not present at the shareholders' meeting (ratio) & $89 \%$ & $90 \%$ & $84 \%$ & $85 \%$ \\
\hline
\end{tabular}

Note. Source: our elaboration on corporate documents.

Summarizing, the presence at the general sharehoders' meeting is almost wholly regarding the relevant ownership and nothing for non-relevant ownership.

Non-relevant shareholders do not therefore show different interest for the two agendas, like the relevant shareholders, and thus it is possible to disclaim the initial postulate that the non-relevant shareholders should demonstrate a greater involvement in the shareholders' meeting that regards the amount of dividends. They, therefore, are absent not only in the meetings where the renewal of board can be considered as the full manifestation of control by the relevant shareholder, but even in the meetings from which follows substantially the performance of their investment.

On the contrary, the results of this empirical evidence confirm the initial idea that the control thresholds within listed companies are presettable exclusively considering all the relevant ownership stakes and, consequently, they show that the $2 \%$ settled by CONSOB is adequate to identify the relevant ownership stake.

\section{Results and Conclusions}

The conclusions of this empirical evidence are the basis of the method suggested in this work to estimate the thresholds of ownership necessary to exercise control.

In general, the shareholder has control over the company when his/her ownership allows him/her to preside over the decision-making process within the company, considering the civil laws on shareholder resolutions relating to the companies that have recourse to the stock market. In particular, the decision-making process is monitored if the ownership consents to realize the quorum established by the Civil Code. ${ }^{1}$

Constitutive quorum, as noted, set the part of the voting capital that must be present at the general sharehoders' meeting.

For the ordinary meeting, the only constitutive quorum concerns the first call, given the need to be present at least half of the voting rights so that the shareholders' meeting is regular.

For the extraordinary general shareholders' meeting, instead, the constitutive quorum also interests the calls after the first, for which is scheduled the same quorum of the ordinary general shareholders' meeting.

\footnotetext{
${ }^{1}$ In order that the results of the investigation are generalizable to most listed companies, were not considered any higher percentage of quorum nor any calls after the second for the extraordinary general meeting, provided for by Articles 2368 and 2369 of the Civil Code.
} 
More precisely, a third of the share capital is required for the second call and a fifth for subsequent calls.

Deliberative quorum sets the part of capital that must vote in favor. In particular, the ordinary general shareholders' meeting deliberates in all the meetings with the absolute majority of the votes while the extraordinary general shareholders' meeting deliberates on the first call by the vote of more than half of the capital and at subsequent calls by favorable vote of at least two thirds of the capital present at the meeting.

Consequently, shareholder concerned to control the decision-making process must carefully determine the capital potentially present at the meeting that, according to the conclusions of this work, can be approximated with the set of relevant ownership.

It is evident that the ownership stake equal to $50 \%$ plus one share ensures the control already in the first call in ordinary and extraordinary general shareholders' meeting. If the ownership is less than $50 \%$, the control is heavily influenced by all the other ownerships that may be present at the meeting.

So for example, if the stake is $40 \%$, the shareholder is able to gain control in the ordinary shareholders' meeting if the total of other ownerships is lower than $40 \%$. In fact, the decisions could not be deliberated on the first call, if other dissenting shareholders agree not to appear in the shareholders' meeting, doing so undermines the constitutive quorum, while the decisions would surely be approved on second call, since no constitutive quorum is set, as said. On the contrary, the stake of $40 \%$ would not be enough to control the decisions in the extraordinary general meeting.

For example, if the total of other relevant ownership is equal to $29 \%$ of the voting stake, the stake of $40 \%$ would not reach the deliberative quorum of two thirds of the capital present at the meeting $(2 / 3$ of $69 \%=46 \%)$. Briefly, this ownership would allow to control the ordinary shareholders' meeting but would not be sufficient to ensure control in the extraordinary one.

It is possible to note, however, that the ownership able to meet the deliberative quorum of two-thirds of the share capital present at the meeting, not necessarily respects the constitutive quorum of one-third of the voting capital.

Thus, for example, if the relevant ownership stakes amount to $36 \%$ of the voting capital, the single ownership stake of $25 \%$ is sufficient for deliberative quorum being more than $20 \%$ or two thirds of the capital present, nevertheless, it is insufficient for the required constitutive quorum, being less than $33 \%$ equal to one third of the voting capital.

Nor, on the other hand, the shareholder can be sure of reaching the quorum with the presence of other relevant shareholders who together hold $11 \%$. In fact, these, might affect the regularity of the extraordinary general meeting not showing up at the meeting, if they intended to influence the decisions of the relevant shareholders.

In essence, the ownership threshold that gives control, having to respect both the quorum, corresponds to the higher value between $33.34 \%$ of the share capital and $66.67 \%$ of the relevant ownership.

Consequently, it is possible to distinguish two threshold values which correspond to two different degrees of control:

- 1 st threshold, which ensures control in both meetings, corresponding to the greater value between $33.34 \%$ of the share capital and $66.67 \%$ of all the relevant ownership;

- 2nd threshold, which guarantees only control at ordinary general meetings, corresponding to $50 \%$ of relevant shareholders.

Table 11 shows the control thresholds of first level relating to different values of the total relevant 
shareholdings. To this end, constitutive quorum is expressed in terms of capital through multiplication of two-thirds by the total number of ownership available that, according to the assumption of this research, coincides with the total of relevant sharehoders.

More specifically, it appears that as long as the total of relevant shareholders is more than $50 \%$ of the voting capital, the ownership that meets the deliberative quorum is sufficient even for the constitutive quorum and, conversely, if the total ownership is less than $50 \%$ of the voting capital. Therefore, the control threshold is represented in the first case exclusively by ownership associated with the deliberative quorum and in the second case is related to the ownership associated to constitutive quorum.

Table 11

Threshold of $1^{\circ}$ Grade - Control in Both Shareholders' Meeting

\begin{tabular}{llll}
\hline Relevant ownership & Deliberative quorum & Constitutive quorum & Threshold \\
\hline $90.00 \%$ & $60.00 \%$ & $33.34 \%$ & $60.00 \%$ \\
$80.00 \%$ & $53.34 \%$ & $33.34 \%$ & $53.34 \%$ \\
$70.00 \%$ & $46.67 \%$ & $33.34 \%$ & $46.67 \%$ \\
$60.00 \%$ & $40.00 \%$ & $33.34 \%$ & $40.00 \%$ \\
$50.00 \%$ & $33.34 \%$ & $33.34 \%$ & $33.34 \%$ \\
$40.00 \%$ & $26.67 \%$ & $33.34 \%$ & $33.34 \%$ \\
$30.00 \%$ & $20.00 \%$ & $33.34 \%$ & $33.34 \%$ \\
$20.00 \%$ & $13.34 \%$ & $33.34 \%$ & $33.34 \%$ \\
$10.00 \%$ & $6.67 \%$ & $33.34 \%$ & $33.34 \%$ \\
\hline
\end{tabular}

Note. Source: our elaboration.

This analysis confirms the initial idea that only the relevant shareholders participate in the meetings and also shows that the percentage set by CONSOB is adequate to identify the investments that are actually relevant to the control. There are not major differences between the two agendas regarding the approval of the annual financial statement and the renewal of board.

On these empirical results, the work develops and suggests a method of estimating the control threshold that differs from the approach prevalent in the literature and based on $20 \%$ of the ownership stake needed to exercise control. In fact, the method suggested is not based on a predefined and indistinct size for all companies but, on the contrary, takes into account the actual relevant ownership within the various ownership structures.

This research can lead to further studies and development, through the extension of the empirical analysis to a cross-country scenario, in which it proceeds with the analysis of the different rules and laws then with the empirical verification of general shareholders' meetings and to conclude, therefore, identifying control thresholds distinct for different countries.

\section{References}

Berle, A., \& Means, G. (1932). The modern corporation and private property. New York: MacMillan. Baumol, W. (1959). Business behavior, value and growth. New York: MacMillan.

Barca, F., \& Becht, M. (2010). The control of corporate Europe. Oxford: Oxford University Press.

Barclay, M. J., \& Holderness, C. G. (1989). Private benefits from control of public corporations. Journal of Financial Economics, 25, 371-395.

Barclay, M. J., Holderness, C. G., \& Pontiff, J. (1993). Private benefits from block ownership and discounts on closed-end fund. Journal of Financial Economics, 3, 263-291. 
Barontini, R., \& Caprio, L. (2006). The effect of family control on firm value and performance: Evidence from continental Europe. European Financial Management, 12, 689-723.

Bebchuk, L. (1999). A rent-protection theory of corporate ownership and control. NBER Working Paper No. 7203.

Bigelli, M., \& Mengoli, S. (2004). Sub-optimal acquisition decision under a relevant ity shareholder system. Journal of Management and Governance, 8, 373-405.

Brioschi, F., Buzzacchi, L., \& Colombo, M. G. (1989). Risk capital financing and the separation of ownership and control in business groups. Journal of Banking and Finance, 13, 747-772.

Claessens, S., Djankov, S., \& Lang, L. H. P. (2000). The separation of ownership and control in East Asian corporations. Journal of Financial Economics, 58, 81-112.

DeAngelo, H., \& DeAngelo, S. (1985). Managerial ownership of voting rights. Journal of Financial Economics, 14, 36-39.

Demsetz, H. (1983). Corporate control, insider trading, and rates of return. American Economic Review, 86, 313-316.

Demsetz, H., \& Lehn, K. (1985). The structure of corporate ownership: Causes and consequences. Journal of Political Economy, 93, 1155-1177.

Dyck, A. (2000). Ownership structure, legal protections and corporate governance. In B. Pleskovic, \& N. Stern (Eds.), 2000 Annual World Bank Conference on Development Economics (pp. 291-330).

Dyck, A. (2001). Privatization and corporate governance: Principles, evidence and future challenges. World Bank Research Observer, 16(1), 59-84.

Dyck, A., \& Zingales, L. (2004). Private benefits of control: An international comparison. Journal of Finance, 59, 537-600.

Faccio, M., \& Lang, L. H. P. (2002). The ultimate ownership of Western European corporations. Journal of Financial Economics, 65, 365-395.

Grossman, S., \& Hart, O. (1980). Takeover bids, the free rider problem, and the theory of the corporation. Bell Journal of Economics, 11, 42-69.

Grossman, S., \& Hart, O. (1986). The costs and benefits of ownership: A theory of vertical and lateral integration. Bell Journal of Economics, 11, 42-64.

Grossman, S., \& Hart, O. (1988). One share one vote and the market for corporate control. Journal of Financial Economics, 20(1-2), 175-202.

Harris, M., \& Raviv, A. (1988). Corporate governance: Voting rights and relevant ity rules. Journal of Financial Economics, 20, 203-235.

Holderness, C. G., \& Sheehan, D. P. (1988). The role of relevant ity shareholders in publicly held corporations: An exploratory analysis. Journal of Financial Economics, 20, 317-346.

Intrisano, C. (2012). Control-enhancing mechanisms in italian companies. China-USA Business Review, 11(3),48-78.

Intrisano, C., \& Rossi, F. (2012). Do M\&As generate value for shareholders': An analysis of the Italian banking sector. Chinese Business Review, 11(2), 206-216.

Jensen, M., \& Meckling, W. (1976). Theory of the firrm: Managerial behavior, agency costs, and ownership structure. Journal of Financial Economics, 3, 305-360.

La Porta, R., Lopez-de-Silanes, F., \& Shleifer, A. (2000). Investor protection and corporate governance. Journal of Financial Economics, 59(1-2), 3-27.

La Porta, R., Lopez-de-Silanes, F., Shleifer, A., \& Vishny, R. (1997). Legal determinants of external finance. Journal of Finance, 53(1), 1131-1150.

La Porta, R., Lopez-de-Silanes, F., \& Shleifer, A. (1999). Corporate ownership around the world. Journal of Finance, 54, 471-517.

Lease, R., McConnell, J., \& Mikkelson, W. H. (1984). The market value of differential votino rights in closely held corporations. Journal of Business, 57(4), 443-467.

Lease, R., McConnell, J., \& Mikkelson, W. H. (1983). The market value of control in publicly-traded corporations. Journal of Financial Economics, 11(1-4), 439-471.

Lopez-de-Silanes, F. (1997). Determinants of privatization prices. The Quarterly Journal of Economics, 4, 965-1025.

Laeven, L., \& Levine, R. (2008). Complex ownership structures and corporate valuations. Review of Financial Studies, 21, 579-604.

Maury, B., \& Pajuste, A. (2005). Multiple large shareholders and firm value. Journal of Banking and Finance, 29, $1813-1834$.

Morck, R., Shleifer, A., \& Vishny, R. (1988). Management ownership and market valuation: An empirical analysis. Journal of Financial Economics, 20, 293-315. 
Nenova, T. (2003). The value of corporate voting rights and control: A cross-country analysis. Journal of Financial Economics, $68,325-351$.

Shleifer, A., \& Vishny, R. (1986). Large shareholders and corporate control. Journal of Political Economy, 94, 461-488.

Shleifer, A., \& Vishny, R. (1997). A survey of corporate governance. Journal of Finance, 52, 737-783.

Villalonga, B., \& Amit, R. (2006). How do family ownership, management and control affect firm value? Journal of Financial Economics, 80, 385-417.

Zingales, L. (1994). The value of the voting right: A study of the Milan stock exchange experience. Review of Financial Studies, 7 , 125-148.

Zingales, L. (1995). What determines the value of corporate votes? Quarterly Journal of Economics, 110, 1047-1073. 